\title{
Bone Marrow Harvesting for HSCT
}

\author{
Norbert Claude Gorin
}

\subsection{Introduction}

Historically, the bone marrow (BM) has been the first source of stem cells considered since the early 1960s for HSCT (Santos 1990; Thomas et al. 1979; Mathe 1964; Gorin et al. 1990). Parallel attempts at using fetal liver cells at that time have remained unsuccessful. In 1986 the first success of an unrelated cord blood (UCB) transplantation in a child promoted UCB (Gluckman et al. 1997) as an alternative source in certain settings.

Since 1994 and the initial demonstration that PBSC mobilized by cytokines (G-CSF first and more recently when needed plerixafor) could be used as well as BM, the proportion of PB transplants has considerably increased to reach about 70-95\% of all stem cell transplants (Passweg et al. 2012, 2016), so that nowadays BM transplantation accounts for a minority of transplants.

There remain however several situations where and when a marrow harvest can still be of interest or even is highly recommended.

This chapter indicates the principal indications of BM transplantation, compares schemati-

N. C. Gorin MD, PhD ( $₫)$

Department of Hematology and Cell Therapy, EBMT Paris Office, Hôpital Saint Antoine APHP, Paris, France

Paris Sorbonne University, Paris, France e-mail: norbert-claude.gorin@aphp.fr cally the advantages of $\mathrm{BM}$ versus $\mathrm{PB}$, and details the technique of BM harvesting.

\subsection{Indications for Considering and Possibly Selecting BM as a Preferred Source of HSC}

It is not the purpose of this chapter to review the benefit/risk ratio of BM versus peripheral mobilized blood as sources of HSC. Several studies, including prospective randomized studies, have shown in general with BM when compared to PB slower engraftment but lower incidence and lower severity of acute and chronic GVHD with in the end similar disease free and overall survivals (Schmitz et al. 2005). However, some retrospective studies for both auto- and allo-HSCT have shown better survival with rich BM collections (Gorin et al. 2003) or BM versus PB (Gorin et al. 2009, 2010). Also, the quality of life has not been carefully analyzed (Sun et al. 2010), and further studies may be in favor of BM (Ruggeri et al. 2018; Lee et al. 2016).

Time and cost constraints have however in general favored leukaphereses and PB transplants which represent about $95 \%$ of all auto-HSCT and $70 \%$ of allo-HSCT (Passweg et al. 2016). Table 14.1 lists the situations when nowadays marrow may appear as a better choice.

For allo-HSCT, BM is preferred/mandatory whenever the wish to reduce toxicity, NRM, and most of all GVHD (particularly extensive chronic) 
Table 14.1 Preferences for BM as source of stem cells in ALLO-HSCT

\begin{tabular}{|c|c|c|c|c|}
\hline Allo-HSCT & Rationale & Justification 1 & Justification 2 & Reference \\
\hline $\begin{array}{l}\text { Children donors } \\
\text { and/or recipients }\end{array}$ & $\begin{array}{l}\text { Administration of } \\
\text { GCSF to and } \\
\text { leukapheresis of the } \\
\text { donor more difficult to } \\
\text { set }\end{array}$ & $\begin{array}{l}\text { More cGVHD and } \\
\text { NRM after PB } \\
\text { compared with BM }\end{array}$ & $\begin{array}{l}\text { In some countries, } \\
\text { the use of GCSF } \\
\text { (and plerixafor) is } \\
\text { not allowed in } \\
\text { children }\end{array}$ & Simonin et al. (2017) \\
\hline Aplastic anemia & $\begin{array}{l}\text { BM mandatory, } \\
\text { associated with better } \\
\text { results }\end{array}$ & $\begin{array}{l}\text { Higher risk of } \\
\text { GVHD with PB }\end{array}$ & $\begin{array}{l}\text { Included in EBMT } \\
\text { and CIBMTR } \\
\text { guidelines }\end{array}$ & $\begin{array}{l}\text { Bhella et al. (2018), } \\
\text { Schrezenmeier et al. } \\
\text { (2007), Bacigalupo et al. } \\
\text { (2012), Eapen et al. (2011), } \\
\text { and Barone et al. (2015) }\end{array}$ \\
\hline $\begin{array}{l}\text { MAC with a } \\
\text { MUD and no } \\
\text { ATG }\end{array}$ & $\begin{array}{l}\text { BM associated with } \\
\text { better results and less } \\
\text { cGVH }\end{array}$ & $\begin{array}{l}\text { Randomized trial } \\
\text { with no ATG } \\
\text { showing less cGVH } \\
\text { and better QOL with } \\
\text { BM }\end{array}$ & $\begin{array}{l}\text { If a suitable BM } \\
\text { donor is available. } \\
\text { Otherwise PB with } \\
\text { ATG }\end{array}$ & $\begin{array}{l}\text { Anasetti et al. (2012), Lee } \\
\text { et al. (2016), Eapen et al. } \\
\text { (2007), and Walker et al. } \\
\text { (2016) }\end{array}$ \\
\hline $\begin{array}{l}\text { Haploidentical } \\
\text { transplantation }\end{array}$ & $\begin{array}{l}\text { BM or combination of } \\
\text { PB and BM favored by } \\
\text { some teams }\end{array}$ & $\begin{array}{l}\text { Team choice or } \\
\text { clinical trial }\end{array}$ & $\begin{array}{l}\text { High-dose CY for } \\
\text { GVH prevention }\end{array}$ & $\begin{array}{l}\text { Kasamon et al. (2017) and } \\
\text { Luznik et al. (2010) }\end{array}$ \\
\hline
\end{tabular}

is considered as priority, such as for children with aplastic anemia and for some teams for haploidentical transplantation (see Table 14.1). The outcome considered to favor this choice is the GRFS (GVHD and relapse-free survival) as defined by EBMT (Ruggeri et al. 2016).

Conversely, PB can be a first choice in patients with hematological malignancies at high or very high risk of progression/relapse, such as AML FLT3ITD positive, lymphomas in progression after relapse from auto-HSCT, etc. for whom the risk of relapse is considered as first priority despite the risk of increasing NRM. Usually, this choice is made in parallel to the decision whether the conditioning regimen should be MAC or RIC (Gilleece et al. 2018).

For autologous HSCT (Table 14.2) the two major reasons for using $\mathrm{BM}$ are autologous transplantation for AML in remission and attempts at increasing the stem cell dose infused following poor marrow collections.

\subsection{Mobilized or Primed Marrow}

Following the discovery of cytokines, G-CSF in particular, the use of BM collected after 2-4 days of GCSF administration has been investigated in the year 2000-2005. G-CSF-primed marrow harvesting results in a graft with more mononuclear cells collected and higher CD34(+) stem and progenitor cell doses s (Grupp et al. 2006). The clinical significance of different HSC sources (primed marrow, mobilized blood, and steady-state marrow) in auto- and allo-HSCT was reviewed in 2004 (Elfenbein and Sackstein 2004). Mobilized marrow speeds up engraftment for both auto- and allo-HSCT, with a possible (unproven) reduction of GVHD rate and severity. Its use nowadays is rare, but it is for some teams the preferred stem cell source or part of a combination of primed marrow + PB as stem cell source for haploidentical donor transplantation (Huang et al. 2009; Ly et al. 2015).

\subsection{Technique of BM Collection and Impact of the Dose of Nucleated Cells Infused}

Marrow is collected from the posterior superior iliac crests, usually under general anesthesia, although few teams have used sedation or locoregional anesthesia (Fig. 14.1).

Marrow is aspirated with bone needles with multiple holes all around, which makes collection easier and the procedure more rapid. However, to avoid large dilution with blood, it is recommended to limit each aspiration to a volume of less than $5 \mathrm{~mL}$, before transferring the 


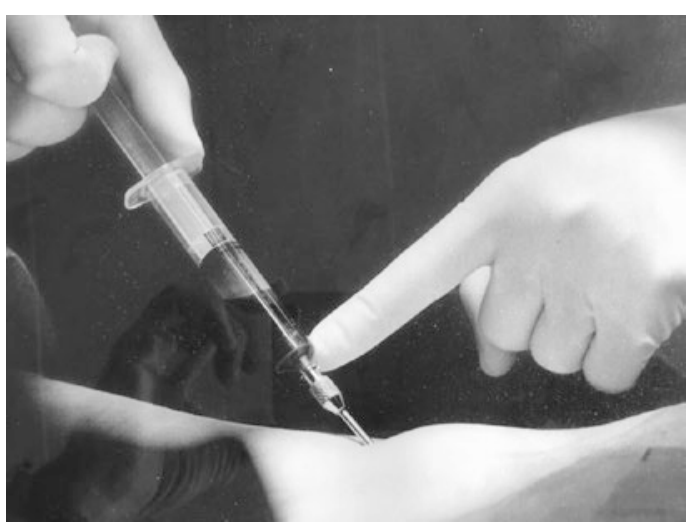

Fig. 14.1 Bone marrow harvest

aspirate through a three-way tap to the collection bag. The collection bag contains ACD anticoagulant solution and the syringes are rinsed with heparin $(5.000 \mathrm{U} / \mathrm{mL})$.

The goal is nowadays to obtain typically at least $3 \times 10^{8}$ nucleated cells $/ \mathrm{kg}$, although $2 \times 10^{8}$ nucleated cells $/ \mathrm{kg}$ has long been in the past the usual target and remains acceptable. However, it should be kept in mind that old studies in the early development of BMT have indicated better results both in terms of engraftment but also decrease in NRM and RI and better outcome, with higher marrow doses (Gorin et al. 1999, 2003; Sierra et al. 1997):

- For Allo-HSCT with identical siblings, an early EBMT retrospective study evaluated the impact of the marrow cell dose infused: The median BM cell dose was $2.7 \times 10^{8} / \mathrm{kg}$ $\left(0.17-29 \times 10^{8} / \mathrm{kg}\right)$. In multivariate analyses, high-dose BM compared to PB was associated with lower NRM, better LFS, and better OS $\quad(\mathrm{RR}=0.64 ; 95 \%$ CI, 0.44-0.92; $P=0.016)$. Results in patients with AML receiving allografts in CR1 indicated a better outcome with BM as compared to PB, when the dose of BM infused was above the median value.

- For Allo-HSCT fully with matched unrelated donors (Sierra et al. 1997), transplantation of a marrow cell dose above the median value of $3.65 \times 10^{8} / \mathrm{kg}$ was associated with faster neutrophil and platelet engraftment and decreased incidence of severe acute GVHD. Transplant in remission of acute leukemia with a high dose of marrow cells was associated with the best outcome in both children and adults.

If the targeted goal cannot be achieved, additional collection can be made from the anterior iliac crests, although it is time consuming and potentially more harmful for the patient or the donor, who must be turned over with all sterile fields to be reinstalled.

All things considered the maximum accepted volume collected should not go over $20 \mathrm{~mL} / \mathrm{kg}$ donor body weight. Depending on the volume collected, three attitudes regarding transfusion during marrow collection may be followed: no transfusion and liquid replacement is the first option for many teams. Autotransfusion (to prepare beforehand in the 3 weeks preceding marrow collection, which adds some constraint) is the other recommended transfusional option. In rare circumstances allo-transfusion remains possible; usually two packs of concentrated red cells are enough.

Another option to consider to increase the stem cell dose to infuse when marrow collection has been insufficiently productive is the addition of PBSC. This however can be a complex decision which should take into account the disease and disease status, whether it concerns an autograft or an allograft or in this last situation whether a possible increase in the incidence and severity of GVHD associated with GVL/tumor is potentially beneficial or harmful. Two examples of this dilemma are summarized below:

1. In the context of auto-HSCT for leukemias or lymphomas, when analyzing patients receiving combinations of BM and PBSC (either because PBSC were collected to supplement poor BM or the reverse), outcomes are poor. One likely explanation is the existence of a bias since in most of these patients, poor collections (either BM or PBSC or both) are surrogate markers of multiple previous lines of chemotherapy for resistant/progressing diseases.

2. In contrast, for some teams, the combination of BM and PBSC has become the standard stem cell source for HSCT (see Table 14.1). 
Table 14.2 Preferences for BM as source of stem cells in AUTO-HSCT

\begin{tabular}{|c|c|c|c|}
\hline $\begin{array}{l}\text { Auto- } \\
\text { HSCT }\end{array}$ & Rationale & Justification & Comments \\
\hline $\begin{array}{l}\text { Poor PB } \\
\text { collection }\end{array}$ & $\begin{array}{l}\text { Increase } \\
\text { the dose of } \\
\text { HSC in the } \\
\text { autograft }\end{array}$ & $\begin{array}{l}\text { Ensure safer } \\
\text { engraftment }\end{array}$ & $\begin{array}{l}\text { However, poor } \\
\text { mobilizers are } \\
\text { likely to also } \\
\text { produce poor } \\
\text { marrow } \\
\text { collection* }\end{array}$ \\
\hline AML & $\begin{array}{l}\text { Outcome } \\
\text { better } \\
\text { when } \\
\text { compared } \\
\text { to PB }\end{array}$ & & $\begin{array}{l}\text { Several EBMT } \\
\text { retrospective } \\
\text { studies }\end{array}$ \\
\hline
\end{tabular}

*Although there are biases, data from the EBMT registry indicate that poor mobilizers (often previously heavily treated with chemotherapy) have a poor outcome Shouval et al. (2018)

\subsection{Complications of Bone Marrow Collections}

One cannot ignore that on theoretical grounds two major hazards of marrow collection although very rare are death secondary to general anesthesia $(<1 / 200,000)$ and major organ damage by mechanical mismanipulation of the bone needles that may sideslip if sufficient expertise and caution are not present.

The NMDP analyzed in 1993, 493 volunteers who donated unrelated marrow from October 1991 in 42 centers (Stroncek et al. 1993). The median volume of marrow collected was $1050 \mathrm{~mL}$ (range 180-2983 mL). Autologous red blood cells were transfused to $90 \%$ of donors, but only three donors received allogeneic blood. Apnea during anesthesia occurred in one donor. Other acute complications related to the collection procedure occurred in $6 \%$ of donors. Following marrow collection $75 \%$ experienced tiredness, $68 \%$ experienced pain at the marrow collection site, and $52 \%$ of the donors experienced low back pain. Mean recovery time was 16 days, but 42 donors felt that it took them at least 30 days to recover fully. The duration of the marrow collection procedure and duration of anesthesia both positively correlated with donor pain and/or fatigue following the collection. The recommendation of this study was the duration of the collection procedure and probably the duration of anesthesia, and therefore the volume of marrow collected should be kept to a minimum, but this conclusion is to be weighed against the wish to collect stem cell doses as high as possible to ensure fast engraftment and improve outcome.

\subsection{Bone Marrow Cryopreservation}

In the context of auto-HSCT, BM and PBSC are almost always cryopreserved and stored either in liquid nitrogen $\left(-196^{\circ} \mathrm{C}\right)$ or the gas phase of liquid nitrogen $\left(-140{ }^{\circ} \mathrm{C}\right)$. The technique of freezing at $-1{ }^{\circ} \mathrm{C} / \mathrm{min}$ with dimethyl sulfoxide (DMSO) and the technique of rapid thawing are well established (Gorin 1986). Harmless long duration of storage has been reported up to 11 years (Aird et al. 1992). Recently some attempts at avoiding cryopreservation to replace it by storage at $4{ }^{\circ} \mathrm{C}$ in the refrigerator have produced interesting results, but using refrigerator storage is not presently validated and cannot be recommended by EBMT (Sarmiento et al. 2018).

Cryopreservation and storage of a marrow in view of an allo-HSCT is possible. However, it should be kept in mind that any cryopreservation procedure, would it seem perfect, results in some measurable (CFU-GM, BFU-E) and many less measurable (immune functions, etc.) damages. Therefore, it should be reserved to special situations when, for instance, the donor cannot be available at the very time of the transplantation procedure. As a rule, fresh marrow is preferable to frozen marrow.

\subsection{Quality Control for BM Harvesting and Cryopreservation}

The major indicator for successful BM collection is the dose collected, as discussed above, i.e., the number of nucleated cells expressed per $\mathrm{kg}$ of 
body weight for the recipient. It is very usual to have a blood count done at the mid time of the collection to ensure proper richness. With a goal of a minimum of $3 \times 10^{8}$ nucleated cells $/ \mathrm{kg}$, any richness above this value can be seen as a bonus. Harvest below this level, around $2 \times 10^{8}$ or even lower, however has been associated with correct engraftment.

CD34+ evaluation is not routinely performed for $\mathrm{BM}$, while it is the rule for $\mathrm{PB}$.

For cryopreserved marrow, some teams routinely cryopreserve small samples in minibags or ampoules, enabling viability testing before thawing the graft (usually an autograft). However, and importantly, a technical bias has been observed with ampoules since differences in cooling rates prevent ampoules from being a reliable index of HSC cryopreservation in large volumes (Douay et al. 1986a).

More pertinent testing consists in the evaluation of CFU-GM which represents in this setting the most reliable functional viability indicator (Douay et al. 1986b). Although there is no guideline, experience has shown that the results in CFUGM/kg are about 1-1.5 log below the expected or calculated results in CD34+ cells $/ \mathrm{kg}$ (therefore expressed in $10^{5} / \mathrm{kg}$ ). CFU-GM evaluation is not a consensual prerequisite since it is an additional time-consuming effort, but it may bring important information in some cases, for instance, when dealing with marrow collections below $2 \times 10^{8} / \mathrm{kg}$.

\subsection{Conclusions}

PB collections and transplantation nowadays represent $70-90 \%$ of all stem cell sources for transplants.

However, BM transplantation has not disappeared and is likely to persist in some limited situations and indications.

Further studies may revisit and increase the choice of marrow as stem cell source.
The Five Key Points of Marrow Collection

- Harvest with small $(2-5 \mathrm{~mL})$ aspirate volumes to avoid dilution with blood.

- The goal should be at least $3 \times 10^{8}$ nucleated cells per $\mathrm{kg}$, but the more the better. The maximum volume collected should not go over $20 \mathrm{~mL} / \mathrm{kg}$ donor body weight. Decision for no transfusion with liquid replacement (recommended) or autotransfusion (second best option) or in rare cases Allotransfusion during collection relies on the judgment of the local medical team.

- Cryopreservation is the rule for autoBMT, while it should be avoided and used only in rare specific conditions for allogeneic transplantation.

- $\mathrm{BM}$ is mandatory in children and patients with aplastic anemias. It is presently favored by some teams in the context of haploidentical transplantation.

- BM when compared with PBSC results in less NRM, less GVHD (in particular less chronic extensive GVHD), but less GVL/lymphoma/tumor effect.

\section{References}

Aird W, Labopin M, Gorin NC, Antin JH. Long-term cryopreservation of human stem cells. Bone Marrow Transplant. 1992;9:487-90.

Anasetti C, Logan BR, Lee SJ, et al. Peripheral-blood stem cells versus bone marrow from unrelated donors. N Engl J Med. 2012;367:1487-96.

Bacigalupo A, Socie G, Schrezenmeier H, et al. Bone marrow versus peripheral blood as the stem cell source for sibling transplants in acquired aplastic anemia: survival advantage for bone marrow in all age groups. Haematologica. 2012;97:1142-8.

Barone A, Lucarelli A, Onofrillo D, et al. Diagnosis and management of acquired aplastic anemia in childhood. Guidelines from the marrow failure study group of the pediatric haemato-oncology Italian association (AIEOP). Blood Cells Mol Dis. 2015;55:40-7.

Bhella S, Navneet S, Majhail NS, Betcher J, et al. Choosing wisely BMT: American society for blood 
and marrow transplantation and Canadian blood and marrow transplant group's list of 5 tests and treatments to question in blood and marrow transplantation. Biol Blood Marrow Transplant. 2018;24:909-13.

Douay L, Lopez M, Gorin NC. A technical bias: differences in cooling rates prevent ampoules from being a reliable index of stem cell cryopreservation in large volumes. Cryobiology. 1986a;23:296-301.

Douay L, Gorin NC, Mary JY, et al. Recovery of CFUGM from cryopreserved marrow and in vivo evaluation after autologous bone marrow transplantation are predictive of engraftment. Exp Hematol. 1986b;14:358-65.

Eapen M, Logan BR, Confer DL, et al. Peripheral blood grafts from unrelated donors are associated with increased acute and chronic graft-versus-host disease without improved survival. Biol Blood Marrow Transplant. 2007;13:1461-8.

Eapen M, Le Rademacher J, Antin JH, et al. Effect of stem cell source on outcomes after unrelated donor transplantation in severe aplastic anemia. Blood. 2011;118:2618-21.

Elfenbein GJ, Sackstein R. Primed marrow for autologous and allogeneic transplantation: a review comparing primed marrow to mobilized blood and steady-state marrow. Exp Hematol. 2004;32:327-39.

Gilleece M, Labopin M, Yakoub-Agha I, et al. Measurable residual disease, conditioning regimen intensity and age predict outcome of allogeneic hematopoietic cell transplantation for acute myeloid leukaemia in first remission: a registry analysis of 2292 patients by the acute leukemia working party European society of blood and marrow transplantation. Am J Hematol. 2018;93:1142-52.

Gluckman E, Rocha V, Boyer-Chammard A, et al. Outcome of cord-blood transplantation from related and unrelated donors. Eurocord transplant group and the European blood and marrow transplantation group. N Engl J Med. 1997;337:373-81.

Gorin NC. Collection, manipulation and freezing of haemopoietic stem cells. Clin Haematol. 1986;15:19-48.

Gorin NC, Aegerter P, Auvert B, et al. Autologous bone marrow transplantation for acute myelocytic leukemia in first remission: a European survey of the role of marrow purging. Blood. 1990;75:1606-14.

Gorin NC, Labopin M, Laporte JP, et al. Importance of marrow dose on posttransplant outcome in acute leukemia: models derived from patients autografted with mafosfamide-purged marrow at a single institution. Exp Hematol. 1999;27:1822-30.

Gorin NC, Labopin M, Rocha V, et al. Marrow versus peripheral blood for geno-identical allogeneic stem cell transplantation in acute myelocytic leukemia: influence of dose and stem cell source shows better outcome with rich marrow. Blood. 2003;102:3043-51.

Gorin NC, Labopin M, Blaise D, et al. Higher incidence of relapse with peripheral blood rather than marrow as a source of stem cells in adults with acute myelocytic leukemia autografted during the first remission. J Clin Oncol. 2009;27:3987-93.
Gorin NC, Labopin M, Reiffers J, et al. Higher incidence of relapse in patients with acute myelocytic leukemia infused with higher doses of CD34+ cells from leukapheresis products autografted during the first remission. Blood. 2010;116:3157-62.

Grupp SA, Frangoul H, Wall D, et al. Use of G-CSF in matched sibling donor pediatric allogeneic transplantation: a consensus statement from the Children's Oncology Group (COG) Transplant Discipline Committee and Pediatric Blood and Marrow Transplant Consortium (PBMTC) Executive Committee. Ped Blood Cancer. 2006;46:414-21.

Huang XJ, Liu DH, Liu KY, et al. Treatment of acute leukemia with unmanipulated HLA-mismatched/haploidentical blood and bone marrow transplantation. Biol Blood Marrow Transplant. 2009;15:257-65.

Kasamon YL, Ambinder RF, Fuchs EJ, et al. Prospective study of nonmyeloablative, HLA-mismatched unrelated BMT with high-dose posttransplantation cyclophosphamide. Blood Adv. 2017;1:288-92.

Lee SJ, Logan B, Westervelt P, et al. Comparison of patient-reported outcomes in 5-year survivors who received bone marrow vs peripheral blood unrelated donor transplantation: long-term follow-up of a randomized clinical trial. JAMA Oncol. 2016;2:1583-9.

Luznik L, Bolanos-Meade J, Zahurak M, et al. Highdose cyclophosphamide as single-agent, short-course prophylaxis of graft-versus-host disease. Blood. 2010;115:3224-30.

Ly M, Zhao XS, Hu Y, et al. Monocytic and promyelocytic myeloid-derived suppressor cells may contribute to G-CSF-induced immune tolerance in haplo-identical allogeneic hematopoietic stem cell transplantation. Am J Hematol. 2015;90:E9-E16.

Mathe G. Treatment of leukemia with allogenic bone marrow transplantation. Brux Med. 1964;44:559-62.

Passweg JR, Baldomero H, Gratwohl A, Bregni M, Cesaro S, Dreger P, et al. The EBMT activity survey: 19902010. Bone Marrow Transplant. 2012;47:906-23.

Passweg JR, Baldomero H, Bader P, et al. Hematopoietic stem cell transplantation in Europe 2014: more than 40000 transplants annually. Bone Marrow Transplant. 2016;51:786-92.

Ruggeri A, Labopin M, Ciceri F, et al. Definition of GvHDfree, relapse-free survival for registry-based studies: an ALWP-EBMT analysis on patients with AML in remission. Bone Marrow Transplant. 2016;51:610-1.

Ruggeri A, Labopin M, Bacigalupo A, et al. Bone marrow versus mobilized peripheral blood stem cells in haploidentical transplants using posttransplantation cyclophosphamide. Cancer. 2018;124:1428-37.

Santos GW. Bone marrow transplantation in hematologic malignancies. Current status. Cancer. 1990;65(3 Suppl):786-91.

Sarmiento M, Ramirez P, Parody R, et al. Advantages of non-cryopreserved autologous hematopoietic stem cell transplantation against a cryopreserved strategy. Bone Marrow Transplant. 2018;53:960-6. https://doi. org/10.1038/s41409-018-0117-5. 
Schmitz N, Beksac M, Bacigalupo A, et al. Filgrastimmobilized peripheral blood progenitor cells versus bone marrow transplantation for treating leukemia: 3-year results from the EBMT randomized trial. Haematologica. 2005;90:643-8.

Schrezenmeier H, Passweg JR, Marsh JC, et al. Worse outcome and more chronic GVHD with peripheral blood progenitor cells than bone marrow in HLA-matched sibling donor transplants for young patients with severe acquired aplastic anemia. Blood. 2007;110:1397-400.

Shouval R, Labopin M, Bomze D, et al. Prediction of leukemia free survival following autologous stem cell transplantation in AML. A risk score developed by the ALWP of the EBMT. EHA $23^{\text {rd }}$ annual meeting, Stockholm, 2018. Abstract.

Sierra J, Storer B, Hansen JA, et al. Transplantation of marrow cells from unrelated donors for treatment of high-risk acute leukemia: the effect of leukemic burden, donor HLA matching and marrow cell dose. Blood. 1997;89:4226-35.

Simonin M, Dalissier A, Labopin M, et al. More chronic GvHD and non-relapse mortality after peripheral blood stem cell compared with bone marrow in hematopoietic transplantation for paediatric acute lymphoblastic leukemia: a retrospective study on behalf of the EBMT Paediatric Diseases Working Party. Bone Marrow Transplant. 2017;52:1071-3.

Stroncek DF, Holland PV, Bartch G, et al. Experiences of the first 493 unrelated marrow donors in the National Marrow Donor Program. Blood. 1993;81:1940-6.

Sun CLFL, Kawashima T, Leisenring W, et al. Prevalence and predictors of chronic health conditions after hematopoietic cell transplantation: a report from the bone marrow transplant survivor study. Blood. 2010;116:3129-39.

Thomas ED, Buckner CD, Clift RA, et al. Marrow transplantation for acute non lymphoblastic leukemia in first remission. N Engl J Med. 1979;301:597-9.

Walker I, Panzarella T, Couban S, et al. Pretreatment with anti-thymocyte globulin versus no anti-thymocyte globulin in patients with haematological malignancies undergoing haemopoietic cell transplantation from unrelated donors: a randomised, controlled, open-label, phase 3, multicentre trial. Lancet Oncol. 2016;17:164-73.

Open Access This chapter is licensed under the terms of the Creative Commons Attribution 4.0 International License (http://creativecommons.org/licenses/by/4.0/), which permits use, sharing, adaptation, distribution and reproduction in any medium or format, as long as you give appropriate credit to the original author(s) and the source, provide a link to the Creative Commons license and indicate if changes were made.

The images or other third party material in this chapter are included in the chapter's Creative Commons license, unless indicated otherwise in a credit line to the material. If material is not included in the chapter's Creative Commons license and your intended use is not permitted by statutory regulation or exceeds the permitted use, you will need to obtain permission directly from the copyright holder. 